\title{
Teacher-Student Relationship in Obstetrics and Gynaecology Department in Different Medical Colleges of Bangladesh
}

\author{
Kazi Taslima*1, Md. Humayun Kabir Talukder ${ }^{2}$
}

\begin{abstract}
:
Introduction: Teacher-student relationship is very important element in education to enhance the effectiveness of teaching and learning process. There are multiple factors affecting this relation. If we analyze these factors and take measures to improve these, there will be better relation; and teaching learning will be improved. Materials \& Methods: This descriptive type of cross-sectional study was carried out in obstetrics and gynaecology department of selected medical colleges of Bangladesh. Five government \& three non-government medical colleges were selected purposively situated both in Dhaka and outside during the period of July 2017 to June 2018. Total 170 students and 30 teachers were responded through self-administered semi-structured questionnaire with five points Likert scale. 20 teachers were responded through in-depth interview schedule. Quantitative data analyzed by SPSS version 19. Qualitative data analyzed manually. Results: Study revealed that multiple factors were related to the relation among medical teachers and students. Mutual respect, empathy, Good listening skill, mutual respect, sharing expectation, self-disclosure, awareness about own role are the most important influencing factors in this relation (mean score $>4$ ). Use of drugs/tobacco, speech difficulty, love affair of students, negatively affect communication. Study also revealed barriers of relation fear and shyness, language barrier and discrimination of students by the teachers. Friendly relationship, open minded behavior, student- teachers cooperation, open discussion, morality and religious practice, motivation of by teachers, understanding each other's, avoidance of student's politics, responsibility of students \& teachers, teachers training with reduced workload have great impact on removing these barriers. Conclusion: Addressing these issues at all possible levels, proper measures should be taken to improve relation among teachers and students; so that teaching learning process can be enhanced and ultimate goal of medical education can be achieved.
\end{abstract}

Key words:Communication, Student, Teacher, Teachers' view, Students' view, Teacher-student relation.

Number of Tables: 02;Number of Figures: 02; Number of References: 20; Number of Correspondences: 06.

*1. Corresponding Author: Dr. Kazi Taslima

Junior Consultant

Department of Obstetrics and Gynaecology

DGHS

Mohakhali, Dhaka.

Email:kazitaslima73@gmail.com

Mobile: +8801 553750752

2. Prof. Dr. Md. Humayun Kabir Talukder

Professor

Department of Curriculum Development and

Evaluation

Center for Medical Education

Mohakhali, Dkaka.

\section{Introduction:}

Teacher-student relationship is very important element in education which is a vital tool for the welfare of the society $^{1}$. Effective relationship between teachers and students is a key factor to enhance the effectiveness of teaching and learning process ${ }^{2}$. Therefore, the effectiveness of the communication is measured by the message sent and feedback received ${ }^{3}$. Effective communication between teachers and students is a key factor to enhance the effectiveness of teaching and learning process ${ }^{4}$. As teaching learning is a two way process and be effective only when there is appropriate relation. There are multiple factors affecting relation among teachers and students in gynae and obstetric department ${ }^{5}$. Student's teaching and learning is one the most important tasks for professors and enhancing the quality of learning plays a key role in professor's motivation and efficiency ${ }^{5}$. There are multiple barriers in communication between teacher and students ${ }^{6}$. There are four types of barriers; these are process barriers, physical barriers, semantic barriers, and psychosocial barriers. Affective factors in improving communication among professors and students are essential for improving the educational process ${ }^{7}$.Trust and mutual understanding among students and professors is one of the important factors in learning and communication of students with professors increases students' confidence and motivation in learning ${ }^{8}$. Different studies addressing this relationship done in abroad but factors may be different in our setting. If we analyze these factors and take measures to improve these, there will be better relation; and teaching learning will be improved.

\section{Materials and Methods:}

This study was descriptive type of cross sectional study. Study period was from July 2016 to June 2017 (one year). The study was carried out among undergraduate medical students of fourth phase and teachers of all levels (lecturer to professor). Fives public and three non-government medical colleges were included. Fives (three public \& two non-govt.) were within Dhaka and rest were from outside Dhaka. Sample size was 170 students and 50 teachers through self-administered semi- 
structured questionnaire and 20 teachers for in-depth interview. Medical colleges were selected purposively and convenience sampling technique was adopted for data collection. Pretesting of the questionnaire and in-depth interview schedule was done in a medical college other than the study areas. The questionnaire and interview schedule was finalized and Bangla version of questionnaire was adopted. For data collection written permission from the principals of the medical colleges was taken to conduct the study. The study was carried after prior consent from the students and teachers with necessary clarification. They were free to either participate or quiet from study. The filled-up questionnaires were collected from the students at the end of the class and teachers returned those according to their convenience. In-depth interview was conducted according to the teachers' convenience. Researcher was physically present \& helped the respondents during the time of response with probing questioning. Response of in-depth interview was noted and tape recorded by the researcher, when allowed. Data were checked, cleaned and edited after collection and then processed and analyzed by computer software SPSS program (IBM SPSS statistics 19). Likert scale was used to measure responses of the respondents of each item. Scores were given to each scale as: strongly agree $=5$, agree $=4$, neither agreenor disagree $=3$, disagree $=2$, strongly disagree $=1$.

Interpretation of the mean scores were:

If mean score was $>4$ : situation of the item areas was highly satisfactory

If mean score was $>3-4$ : situation of the item areas was satisfactory

If mean score was $>2-3$ : situation of the item areas was not satisfactory

If mean score was 1-2: situation of the item areas was very poor in satisfaction

Data derived from in-depth interview was scrutinized immediately on the day of interview. Coding was done on the left margin and comments and reactions were noted on the right margin of the sheets. Useful quotations were identified immediately. Open questions and in depth interview analyzed manually.

Results:

Total 170 students and 70 teachers participated in this study.

Figure 1 Bar diagram shows that among 170students around $65 \%$ (110) students from govt. medical colleges and around $35 \%$ (60) from non govt. medical colleges.

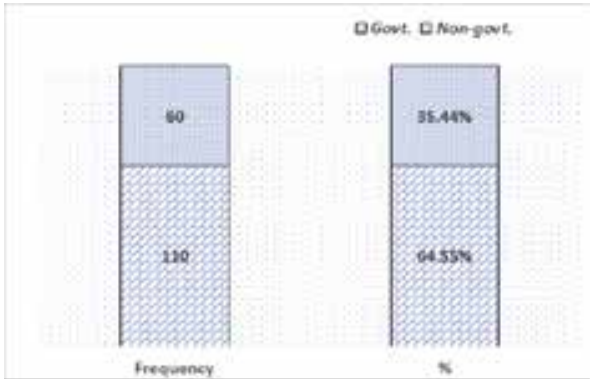

Figure-1: Distribution of students by types of medical colleges.
Fig 2 Bar diagram shows that out of 170 students; 102 (around 60\%) respondents were female and 68 (around $40 \%$ ) were male.

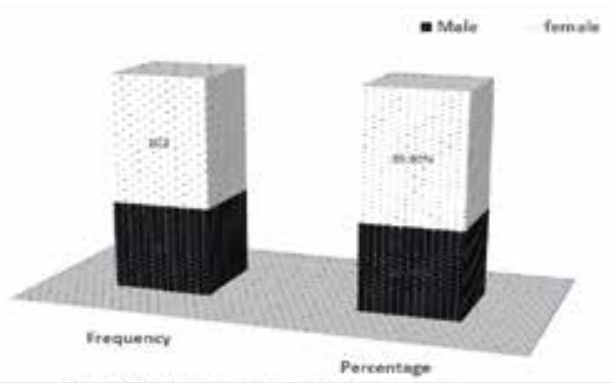

Figure-2: Distribution of students by gender.

Figure 3 Pie diagram shows that out of $70 ; 40$ teachers $(56 \%)$ were from government medical college and 30 teachers $(44 \%)$ were from non govt. medical colleges.

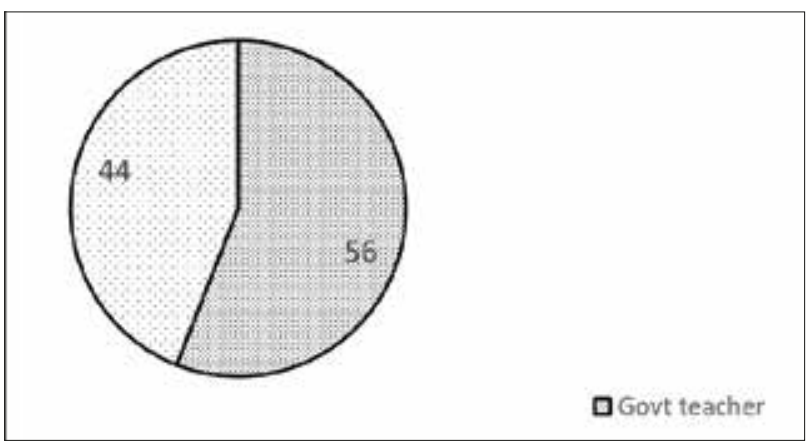

Figure-3: Distribution of teachers by types of their medical college.

Table I shows that these factors have strong positive influence on student teachers' relation (overall mean=4.08), reversed scoring was done before analysis in two factors ; use of drug/tobacco and love affair of students due to negativity of these questions and these two factors negatively influences communication (means are 3.83 \& 3.08).

Table-I: Distribution of medical students' opinion regarding the personal factors that influence teacher-student relation $(n=170)$ :

\begin{tabular}{|c|c|c|c|c|c|c|}
\hline \multirow{4}{*}{ Factors } & \multicolumn{5}{|c|}{ Level of agreement } & \multirow{4}{*}{ Mean $( \pm \mathrm{SD})$} \\
\hline & \multicolumn{5}{|c|}{\begin{tabular}{|l} 
(corresponding score) \\
\end{tabular}} & \\
\hline & SDA (1) & $\mathrm{DA}(2)$ & NAND (3) & $\Lambda(4)$ & $\mathrm{SA}(5)$ & \\
\hline & $\%$ & $\%$ & $\%$ & $\%$ & $\%$ & \\
\hline $\begin{array}{l}\text { No speech difficulty of } \\
\text { students }\end{array}$ & $\begin{array}{c}3 \\
(2.2)\end{array}$ & $\begin{array}{c}11 \\
(6.8)\end{array}$ & $\begin{array}{l}20 \\
(8.3)\end{array}$ & $\begin{array}{c}94 \\
(55.6)\end{array}$ & $\begin{array}{c}46 \\
(27.1)\end{array}$ & $\begin{array}{c}3.98 \\
(0.911)\end{array}$ \\
\hline 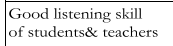 & $\begin{array}{c}2 \\
(.9)\end{array}$ & $\begin{array}{c}3 \\
(1.9)\end{array}$ & $\begin{array}{c}10 \\
(6.1)\end{array}$ & $\begin{array}{c}97 \\
(57.3)\end{array}$ & $\begin{array}{c}57 \\
(33.7)\end{array}$ & $\begin{array}{c}4.321 \\
(0.718)\end{array}$ \\
\hline $\begin{array}{l}\text { Good Communication } \\
\text { skill of students \& } \\
\text { teachers }\end{array}$ & $\stackrel{2}{2}$ & $\begin{array}{c}2 \\
(1.2)\end{array}$ & $\begin{array}{c}5 \\
(3.0)\end{array}$ & $\begin{array}{c}78 \\
(45.8)\end{array}$ & $\begin{array}{c}83 \\
(48.9) \\
\end{array}$ & $\begin{array}{c}4.40 \\
(0.713)\end{array}$ \\
\hline $\begin{array}{l}\text { Use of tobacco /drug } \\
\text { of students }\end{array}$ & $\begin{array}{c}9 \\
9.11) \\
\end{array}$ & $\begin{array}{c}17 \\
(10.1) \\
\end{array}$ & $\begin{array}{c}23 \\
(13.6) \\
\end{array}$ & $\begin{array}{c}66 \\
(38.7) \\
\end{array}$ & $\begin{array}{c}55 \\
(32.5) \\
\end{array}$ & $\begin{array}{c}3.83 \\
(1.139)\end{array}$ \\
\hline \begin{tabular}{|l|}
$\begin{array}{l}\text { Love affair of } \\
\text { students }\end{array}$ \\
\end{tabular} & $\begin{array}{l}18 \\
(10.4) \\
\end{array}$ & $\begin{array}{c}42 \\
(25.0)\end{array}$ & $\begin{array}{c}43 \\
(25.5) \\
\end{array}$ & $\begin{array}{c}41 \\
(24.10) \\
\end{array}$ & $\begin{aligned} 25 \\
(14.6) \\
\end{aligned}$ & $\begin{array}{c}3.08 \\
(0.968)\end{array}$ \\
\hline \begin{tabular}{|l|} 
Students \\
extracurricular activity
\end{tabular} & $\begin{array}{c}5 \\
(3.2) \\
\end{array}$ & $\begin{array}{l}12 \\
(6.8)\end{array}$ & $\begin{array}{c}15 \\
(8.9) \\
\end{array}$ & $\begin{array}{c}89 \\
(52.1)\end{array}$ & $\begin{array}{l}49 \\
(29)\end{array}$ & $\begin{array}{c}3.97 \\
(0.968)\end{array}$ \\
\hline \begin{tabular}{|l|} 
Use of media e.g. \\
Facebook by \\
students\& teachers
\end{tabular} & $\begin{array}{c}7 \\
(4.3) \\
\end{array}$ & $\begin{array}{c}14 \\
(8.1) \\
\end{array}$ & $\begin{array}{c}28 \\
(16.2)\end{array}$ & $\begin{array}{l}78 \\
(46) \\
\end{array}$ & $\begin{array}{c}43 \\
(25.5)\end{array}$ & $\begin{array}{c}3.8 \\
(1.043) \\
\end{array}$ \\
\hline $\begin{array}{l}\text { Awareness about own } \\
\text { role (student/teacher) }\end{array}$ & $\begin{array}{c}1 \\
(0.6)\end{array}$ & $\begin{array}{c}3 \\
(1.8) \\
\end{array}$ & $\begin{array}{c}74 \\
(7.6)\end{array}$ & $\begin{array}{c}89 \\
(52.3)\end{array}$ & $\begin{array}{l}64 \\
(37.7) \\
\end{array}$ & $\begin{array}{c}4.25 \\
(0.722) \\
\end{array}$ \\
\hline $\begin{array}{l}\text { Sharing expectation } \\
\text { /role (student/teacher) }\end{array}$ & $\begin{array}{c}1 \\
(0.5)\end{array}$ & $\begin{array}{c}1 \\
(0.8)\end{array}$ & $\begin{array}{c}7 \\
(4.1) \\
\end{array}$ & $\begin{array}{c}82 \\
(48.5) \\
\end{array}$ & $\begin{array}{c}78 \\
(46.1) \\
\end{array}$ & $\begin{array}{l}4.29 \\
(0.680)\end{array}$ \\
\hline \begin{tabular}{|l|l}
$\begin{array}{l}\text { Mutual respect } \\
\text { (student/teacher) }\end{array}$ \\
\end{tabular} & $\begin{array}{c}1 \\
(0.5)\end{array}$ & $\begin{array}{c}2 \\
(1.2) \\
\end{array}$ & $\begin{array}{c}7 \\
(4.1) \\
\end{array}$ & $\begin{array}{c}72 \\
(42.4)\end{array}$ & $\begin{array}{c}88 \\
(51.8) \\
\end{array}$ & $\begin{array}{c}4.44 \\
(0.680)\end{array}$ \\
\hline $\begin{array}{l}\text { Empathy (student/tea } \\
\text { chrr) }\end{array}$ & $\begin{array}{c}2 \\
(1.2) \\
\end{array}$ & $\begin{array}{c}2 \\
(1.2) \\
\end{array}$ & $\begin{array}{c}15 \\
(8.6) \\
\end{array}$ & $\begin{array}{c}72 \\
(42.5)\end{array}$ & $\begin{array}{r}79 \\
(46.4) \\
\end{array}$ & $\begin{array}{c}4.32 \\
(0.781) \\
\end{array}$ \\
\hline $\begin{array}{l}\begin{array}{l}\text { Self-disclosure } \\
\text { (student/teachet) }\end{array} \\
\end{array}$ & $\begin{array}{c}1 \\
(1.0)\end{array}$ & $\begin{array}{c}23 \\
(3.8)\end{array}$ & $\begin{array}{l}16 \\
(9.5)\end{array}$ & $\begin{array}{c}65 \\
(38.5)\end{array}$ & $\begin{array}{c}80 \\
47.1)\end{array}$ & $\begin{array}{c}4.27 \\
(0.859)\end{array}$ \\
\hline \begin{tabular}{|l}
$\begin{array}{l}\text { extrovert personality } \\
\text { (student/teacher) }\end{array}$ \\
sude
\end{tabular} & $\begin{array}{c}1 \\
(1.3)\end{array}$ & $\begin{array}{c}6 \\
(4.5)\end{array}$ & $\begin{array}{c}20 \\
(11.7)\end{array}$ & $\begin{array}{c}75 \\
(439)\end{array}$ & $\begin{array}{c}65 \\
(38.5) \\
\end{array}$ & $\begin{array}{c}4.14 \\
(0.885)\end{array}$ \\
\hline
\end{tabular}


Table II shows that these factors have strong positive influence on student teachers' relation (overall mean=3.82), reversed scoring was done before analysis in two factors ; use of drug/tobacco and love affair of students due to negativity of these questions and these two factors negatively influences communication (means are $2.12 \& 2,70$ ).

Table-II: Distribution of medical teachers' opinion regarding the personal factors that influence teacher-student relation $(n=50)$ :

\begin{tabular}{|c|c|c|c|c|c|c|}
\hline \multirow{4}{*}{ Factors } & \multicolumn{5}{|c|}{ Level of agreement } & \multirow{4}{*}{ Mean $( \pm S D)$} \\
\hline & \multicolumn{5}{|c|}{\begin{tabular}{|l} 
(corresponding score) \\
\end{tabular}} & \\
\hline & SDA (1) & $\mathrm{DA}(2)$ & NAND (3) & A (4) & SA (5) & \\
\hline & $\%$ & $\%$ & $\%$ & $\%$ & $\%$ & \\
\hline $\begin{array}{l}\text { No speech difficulty of } \\
\text { students }\end{array}$ & $\begin{array}{c}1 \\
(2)\end{array}$ & $\begin{array}{c}5 \\
(10)\end{array}$ & $\begin{array}{c}4 \\
(8)\end{array}$ & $\begin{array}{c}30 \\
(60)\end{array}$ & $\begin{array}{c}10 \\
(20)\end{array}$ & $\begin{array}{c}3.86 \\
(0.926)\end{array}$ \\
\hline $\begin{array}{l}\text { Good listening skill } \\
\text { of students\& teachers }\end{array}$ & $\begin{array}{l}0 \\
0\end{array}$ & $\begin{array}{c}2 \\
(4)\end{array}$ & $\begin{array}{c}0 \\
(0)\end{array}$ & $\begin{array}{c}38 \\
(76)\end{array}$ & $\begin{array}{c}10 \\
(20)\end{array}$ & $\begin{array}{c}4.12 \\
(0.594)\end{array}$ \\
\hline $\begin{array}{l}\text { Good Communication } \\
\text { skill of students \& } \\
\text { teachers }\end{array}$ & $\begin{array}{c}0 \\
(0)\end{array}$ & $\begin{array}{c}2 \\
(4)\end{array}$ & $\begin{array}{c}5 \\
(10)\end{array}$ & $\begin{array}{l}26 \\
(52)\end{array}$ & $\begin{array}{c}17 \\
(34)\end{array}$ & $\begin{array}{c}4.16 \\
(0.766)\end{array}$ \\
\hline $\begin{array}{l}\text { Use of tobacco /drug } \\
\text { of students }\end{array}$ & $\begin{array}{c}0 \\
(0)\end{array}$ & $\begin{array}{c}6 \\
(12)\end{array}$ & $\begin{array}{c}9 \\
(18)\end{array}$ & $\begin{array}{r}20 \\
(40)\end{array}$ & $\begin{array}{c}15 \\
(30)\end{array}$ & $\begin{array}{c}2.12 \\
(0.982)\end{array}$ \\
\hline $\begin{array}{l}\text { Love affair of } \\
\text { students }\end{array}$ & $\begin{array}{c}1 \\
(2)\end{array}$ & $\begin{array}{c}14 \\
(28)\end{array}$ & $\begin{array}{c}11 \\
(22)\end{array}$ & $\begin{array}{c}17 \\
(34)\end{array}$ & $\begin{array}{c}7 \\
(14)\end{array}$ & $\begin{array}{l}2.70 \\
(1.093)\end{array}$ \\
\hline \begin{tabular}{|l|} 
Students \\
extracurricular activity
\end{tabular} & $\begin{array}{c}2 \\
(4)\end{array}$ & $\begin{array}{l}4 \\
(8)\end{array}$ & $\begin{array}{l}3 \\
(6)\end{array}$ & $\begin{array}{c}34 \\
(68)\end{array}$ & $\begin{array}{c}7 \\
(14)\end{array}$ & $\begin{array}{c}3.80 \\
(0.926)\end{array}$ \\
\hline $\begin{array}{l}\text { Use of media e.g. } \\
\text { Facebook by } \\
\text { students\& teachers }\end{array}$ & $\begin{array}{l}3 \\
(6)\end{array}$ & $\begin{array}{c}8 \\
(16)\end{array}$ & $\begin{array}{c}14 \\
(28)\end{array}$ & $\begin{array}{c}17 \\
(34)\end{array}$ & $\begin{array}{c}8 \\
(16)\end{array}$ & $\begin{array}{c}3.38 \\
(1.123)\end{array}$ \\
\hline $\begin{array}{l}\text { Awareness about own } \\
\text { role (student/teacher) }\end{array}$ & $\begin{array}{c}0 \\
(0)\end{array}$ & $\begin{array}{c}1 \\
(2)\end{array}$ & $\begin{array}{c}2 \\
(4)\end{array}$ & $\begin{array}{c}26 \\
(52)\end{array}$ & $\begin{array}{c}21 \\
(42)\end{array}$ & $\begin{array}{c}4.34 \\
(0.658)\end{array}$ \\
\hline $\begin{array}{l}\text { Sharing expectation } \\
\text { /role (student/teacher) }\end{array}$ & $\begin{array}{c}0 \\
(0)\end{array}$ & $\begin{array}{c}1 \\
(2)\end{array}$ & $\begin{array}{c}3 \\
(6)\end{array}$ & $\begin{array}{c}27 \\
(54)\end{array}$ & $\begin{array}{c}4 \\
(8)\end{array}$ & $\begin{array}{c}34.28 \\
(0.671)\end{array}$ \\
\hline \begin{tabular}{|l|} 
Mutual respect \\
(student/teacher)
\end{tabular} & $\begin{array}{c}0 \\
(0)\end{array}$ & $\begin{array}{c}1 \\
(2)\end{array}$ & $\begin{array}{c}1 \\
(2)\end{array}$ & $\begin{array}{c}24 \\
(48)\end{array}$ & $\begin{array}{c}24 \\
(48)\end{array}$ & $\begin{array}{c}4.42 \\
(0.642)\end{array}$ \\
\hline $\begin{array}{l}\text { Empathy (student/tea } \\
\text { cher) }\end{array}$ & $\begin{array}{c}0 \\
(0)\end{array}$ & $\begin{array}{c}1 \\
(2)\end{array}$ & $\begin{array}{c}4 \\
(8)\end{array}$ & $\begin{array}{c}18 \\
(36)\end{array}$ & $\begin{array}{c}27 \\
(54)\end{array}$ & $\begin{array}{c}4.32 \\
(0.653)\end{array}$ \\
\hline \begin{tabular}{|l} 
Self-disclosure \\
(student/teacher)
\end{tabular} & $\begin{array}{c}1 \\
(2)\end{array}$ & $\begin{array}{c}3 \\
(6)\end{array}$ & $\begin{array}{c}11 \\
(22)\end{array}$ & $\begin{array}{l}26 \\
(52)\end{array}$ & $\begin{array}{c}10 \\
(20)\end{array}$ & $\begin{array}{c}4.42 \\
(0.731)\end{array}$ \\
\hline $\begin{array}{l}\text { extrovert personality } \\
\text { (student/teacher) }\end{array}$ & $\begin{array}{c}0 \\
(0)\end{array}$ & $\begin{array}{c}5 \\
(10)\end{array}$ & $\begin{array}{c}4 \\
(8)\end{array}$ & $\begin{array}{l}30 \\
(60)\end{array}$ & $\begin{array}{c}10 \\
(20)\end{array}$ & $\begin{array}{c}3.86 \\
(.808) \\
\end{array}$ \\
\hline Overall & & & & & & $3.82(1.283)$ \\
\hline
\end{tabular}

\section{Discussion:}

Effective relation between teachers and students is a key factor to enhance the effectiveness of teaching and learning process. The aim of study was to identify the effective factors in relation among students and teachers from the students' and teachers' point of views. This study identified most important personal factors as good listening \& communication skill, awareness about own role, sharing expectation (student/teacher), mutual respect, self-disclosure (student/teacher), extrovert personality of student/teacher. This study consistent with Abedini M who identified humanity and ethical aspects of professors as well as trust and mutual understanding of students and professors as important factor in their relation ${ }^{3}$. This study revealed that motivation of students, cooperation among students have positive influence in communication. These findings are not consistent with the findings of Isman ${ }^{9}$. He described scientific knowledge, quality and mastery of teaching as well as teaching styles are more important than professors' experience which enhance the relationship between teachers and students, thereby improve the teaching and learning process consistent with) Aliasgharpour $\mathrm{M}^{10}$. To be effective, teachers have to try to minimize the barriers to relation with students. By making sure that the room is quiet and well lit; by speaking slowly and clearly; by only using words which the students should be able to understand. However, the most important way to overcome the barriers is two-way communication $^{11}$. Process barriers are sender barrier, encoding barrier, medium barrier decoding barrier, receiver barrier and feedback barrier. Physical barriers include a telephone call, drop-in visitors, and distances between people, walls, and static on the radio. Psychological and social barriers are fields of experience, filtering, and psychological distance ${ }^{12}$. This study revealed that two-way communication by constructive feedback improve relationship. One-way communication where the sender cannot get any feedback is a barrier. Bharti P also showed that interactive view which includes feedback as well as nonverbal communication can overcome this barrier ${ }^{13}$. In this study mutual respect, sharing expectation, understanding each other (table I and table II) enhance relationship and helps to remove barriers. This finding consistent with Beebe. ${ }^{14}$ Eisenberg E M identified mutual understanding and sharing expectation as important factors that improve communication and remove barriers ${ }^{15}$. When creating mutual understanding in communication- physical, psychological and semantic barriers are eliminated ${ }^{16}$. The same word may mean different things to different people. The words we choose, how we use them, and the meaning we attach to them also the technical jargon causes many communication barriers. This problem is semantic ${ }^{17}$. If the source (teacher) of knowledge does not have adequate information about the audience (learners) the interaction will not be effective ${ }^{18}$. The quality in communication and its effects on peoples' lives can be improved once we clarify its meaning and also the meaning of education which is the major concept on which a structured society is based ${ }^{19}$. Our study conclude that student's teaching and learning is one the most important tasks for professors and enhancing the quality of learning plays a key role in professor's motivation and efficiency; this finding is consistent with Zimmerman $\mathrm{T}^{20}$.

\section{Conclusion:}

Effective relationship between medical teacher and students is the key to be succeeded in teaching learning. There are various factors influencing this relation. This cross sectional descriptive study has been done to identify personal factors affecting communication. Teachers and students' views was taken through semi-structured questionnaire and in depth interview of teachers. Multiple personal factors related to the communication between medical teachers and students are identified in this study. Good listening \& communication skill, awareness about own role, sharing expectation (student/teacher), mutual respect, self-disclosure (student/teacher), and extrovert personality of student/teacher. Good personality with extrovert characteristic of teachers creates positive impact. Sharing expectation, open discussion and cooperation between teachers and students can remove the gap in communication. Empathy, sympathy, understanding each other and mutual respect can further improve communication. Proper use of multimedia improve communication in classroom. But excessive use of internet and face book distract attention of students thus hamper teacher- student relationship. Maintaining friendly environment and 
cooperation between teachers and students were identified as most important factors that improve relationship. But very much politeness, crossing the boundary might make the class out of control. So, continuous effort and positive attitude of the teachers with improved teaching skill can motivate students to learn. Positive and friendly environment with open minded behavior can help the students to achieve instructional objectives; making them lifelong learner. Thus, institutional goals can be achieved if there is proper relation between teachers and students.

\section{Conflict of Interest: None.}

\section{Acknowledgement:}

The authors would like to thank all participating students and teachers for taking part in the study. We are greatly indebted to institutional authority including all staffs of medical colleges for their endless support. The authors would also like to thanks specially all teachers of CME and Head of the departments of gynae \& obstetrics in different medical colleges for their continuous guidance.

\section{References}

1. Dabaj F. Analysis of Communication Barriers to Distance Education A Review Study. Online Journal of Communication and Media Technologies. 2011; 1 (1).

https://doi.org/10.29333/ojcmt/2328

2. Duta N. From theory to practice: the barrier to efficient communication in teacher-student relationship. Procedia Social and Behavioral Sciences. 2014; 187( 2015 ):625 - 630. https://doi.org/10.1016/j.sbspro.2015.03.116

3. Abedini M R, Abassi A, Mortazavi F \&Bijarid B. The effective factors on the communication between students and faculty members from student's prospective in Birjand University of Medical Sciences, Procedia - Social and Behavioral Sciences. 2011; 83( 2013 ):94 - 98.

https://doi.org/10.1016/j.sbspro.2013.06.018

4. Shaw GB. The wit and wisdom of George Bernard Shaw. Mineola. NY: Dover Publications; 2011.

5. Osakwe RN. Dimensions of Communication as Predictors of Effective Classroom Interaction. Studies on Home and Community Science. 2009; 3(1): 57-61.

https://doi.org/10.1080/09737189.2009.11885277

6. Margaret C W and Genev a D H. Teachers student relationship. 2009 retrieved on 02/03/2018 from msan.wceruw.org/documents/...educators/Relationships/Teacher $\%$ Relationships.pdf

7. Melissa Sam M.Factors that can influence effective communication and interpersonal interactions in relation to the health and social care industry. Marked By Teachers.2013.avilable from http://www.markedbyteachers.com/ as-and-a-level/healthcare [Accessed 28th April, 2018].
8. Detlef RP. Communication and Effective Teaching. Community Eye Health. 2010; 13(35): 44- 45.

9. Işman A, Dabaj F, Altinay F \& Altinay Z. Communication Barriers in Distance Education. The Turkish Online Journal of Educational Technology. 2003; 2(4):1303-6521.

10. Aliasgharpour M, Monjamed Z, \& Naser N. Factors Affecting Students' Evaluation of Teachers: Comparing Viewpoints of Teachers and Students. Iranian Journal of Medical Education. 2010; 10(2): 186-195.

11. Antos G. Handbook of interpersonal communication. The Hague, The Netherlands: Mouton De Gruyter; 2011.

12. Beebe, Steven A. \& Timothy P M. Students and Teachers. 21st Century Communication: A Reference Handbook. Ed. Thousand Oaks, CA: SAGE. 2012; 350-58.

13. Bharti P. Early Education Conference, retrieved on March 6th 2018 from http://events.edtechreview.in/early-education/2018/

14. Debra A D, Kelley S, Joan A F, Coburn M, Cox S, Pollart S, et al. Barriers to Effective Teaching. Academic Medicine. 2011 April; 86 (4).

https://doi.org/10.1097/ACM.0b013e31820defbe

PMid:21346500

15. Eisenberg E M. Organizational communication: Balancing creativity and constraint. New York, NY: Saint Martin's; 2010 .

16. Espeland K. "Empowering versus enabling in academia." Journal of Nurse Education. 2001; 40(8): 342.

https://doi.org/10.3928/0148-4834-20011101-04

17. Ghademi A, Salehi B. "Student view point about effectiveness factors in communication between students and teachers in Arak University of medical sciences." Journal of arak university med science 2007; 7(1): 149-154. 18. Hubley J. Teaching Eye Health: An Introduction Training: Essential for Effective Eye Health Promotion. Community Eye Health. 2000;13(33): 13-14.

19. Haggarty L \& Postlethwaite K. Strategies for Improving Communication between Teachers and School Students about Learning: a university/school collaborative research project Educational Action Research. 2002; 10(3): 449-478. https://doi.org/10.1080/09650790200200195

20. Zimmerman T, Schmidt L, BeckerJ, Nylan R \& Sundeck R. Narrowing the Gap between Students and Instructors: A Study of Expectations. Transformative Dialogues: Teaching \& Learning Journal. 2014;7 (1). 